О.М. Жарик ${ }^{1}$, А.В. Тристан ${ }^{2}$

${ }^{1}$ Командування Повітряних Сил Збройних Сил Украйни, Вінниця

${ }^{2}$ Харківський національний університет Повітряних Сил ім. I. Кожедуба, Харків

\title{
ВІЙСЬКОВА ОПЕРАЦІЯ АЗЕРБАЙДЖАНУ В НАГІРНОМУ КАРАБАСІ В КОНТЕКСТІ РОЗВИТКУ ПОВІТРЯНИХ СИЛ ЗБРОЙНИХ СИЛ УКРАЇНИ
}

Воєнні конфлікти XXI століття, в тому числі в Нагірному Карабасі, є свідоцтвом, яке вкотре доводить: країни, які мають “нестабільні”, спірні території зобов'язані готуватися до війни, а ретельна підготовка до проведення повітряної наступальної операції - необхідність, якою не можна нехтувати.

Авіачія була та залишається стримуючим фактором для країн агресорів, так більшість бойових втрат Вірменії завдані саме авіацією Збройних Сил Азербайджану. Особливістю подібних конфліктів є збільшення частки в проведенні повітряних операцій безпілотної авіації - ударних безпілотних авіаційних комплексів з ракетно-бомбовим озброєнням, щуо обумовлено високою иіною втрат пілотованої авіації.

У роботі узагальнено висновки війни у Нагірному Карабасі для Повітряних Сил Збройних Сил України та розроблено рекомендації щьодо їх підготовки до збройних конфліктів сучасності та майбутнього.

Ключові слова: “заморожений” конфлікт, збройний конфлікт, повітряна наступальна операція, розвиток Повітряних Сил, безпілотна та пілотована авіації, підготовка та ведення військових операџій.

\section{Вступ}

Постановка проблеми. Незважаючи на декларування прагнення до миру, світ у XXI столітті не став безпечніше. Боротьба з тероризмом у Афганістані, Сирійській арабській республіці, Республіці Ірак, протиріччя на Близькому Сході, “палаюча” Африка (Судан, Лівія, Ефіопія), “заморожені” конфлікти в Європі (Косово, Придністров'я, Абхазія, Південна Осетія), війна на сході України - військові конфлікти різної інтенсивності, які призводять до численних людських жертв, потоку мігрантів та економічних втрат. Ще на початку XXI століття ніхто серйозно не вважав, що перегляд кордонів в Свропі можливий, а в 2009 році Грузія фактично втратила Південну Oceтію, до цього - Абхазію, в 2014 році Україна втратила Крим. Дані тенденції свідчать про вирішення протиріч між країнами шляхом війни, а отже до неї потрібно готуватися. Як готуватися до війни у XXI столітті, які тенденції розвитку збройної боротьби можна спостерігати, як розвивається військове мистецтво в умовах стрімкого розвитку технологій, появи нового озброєння та військової техніки - питання, на які необхідно вміти відповідати для досягнення перемоги у майбутніх війнах та конфліктах.

Метою статті $\epsilon$ узагальнення висновків війни у Нагірному Карабасі для Повітряних Сил Збройних Сил України та розробка рекомендацій щодо їх підготовки до збройних конфліктів сучасності та майбутнього.

Аналіз останніх досліджень і публікацій. Літературні джерела за темою статті умовно можна розділити на три групи. Перша група присвячена теоретичному дослідженню збройних конфліктів сучасності та дозволяе сформувати погляди на розвиток військового мистецтва у XXI столітті. До неї відноситься стаття [1], в якій наведені сучасні зміни до ведення війни та управління; монографія [2], яка присвячена зміні підходів до управління у збройних силах (3С) США; дослідження [3], в якому досить детально описується проведення військових операцій у збройних конфліктах сучасності до 2013 року; стаття [4], яка розкриває еволюційність підходів до підготовки повітряної наступальної операції (ПНО) та ведення протиповітряної оборони (ППО), виходячи 3 досвіду військового конфлікту в Лівії. В статтях [5-6] наводяться теоретичні погляди на особливості застосування саме Повітряних Сил (ПС) ЗС України у сучасних умовах ведення збройної боротьби. Застосування даної групи джерел дозволило сформувати теоретичний базис для проведення аналізу та формування рекомендацій.

До другої групи джерел [7-10] необхідно віднести публікації, які стосуються дослідження розвитку Збройних Сил в цілому та ПС ЗС України на найближчу перспективу 3 урахуванням тенденцій розвитку теорії війн і практичного досвіду виконання завдань в антитерористичній операції (АТО) на сході України та операції Об'єднаних сил (ООС).

Третя група джерел відноситься до відкритих публікацій на тему аналізу війни у Нагірному Карабасі військовими експертами, журналістами [11-14], яка дозволила сформувати висновки щодо змін у підготовці та веденні військових операцій.

\section{Виклад основного матеріалу}

Після розпаду СРСР у 1991 році почали формуватися молоді держави зі своїми елітами, 
збройними силами та територіальними претензіями до сусідів, що стало підгрунтям формування “заморожених" конфліктів у проявах самопроголошених республік: Придністровської Молдавської Республіки, Нагірно-Карабаської Республіки, Республіки Абхазія, Південно-Осетинської Республіки, а також дуже схожий збройний конфлікт на сході нашої держави. Деякі конфлікти: Грузинський, де з 1989 року напруженість в регіоні тричі (1991-1992, 2004, 2008) переростала в масштабні кровопролитні зіткнення, супроводжуюсь численними жертвами та руйнуваннями. Вірмено-азербайджанський конфлікт у Нагірному Карабасі триває вже три десятиліття. Лінія зіткнення в зоні Нагірного Карабаху практично не змінилася за 28 років з часу підписання Бішкекського протоколу про припинення вогню. Звісно, позиційні бої регулярно спалахували, а в квітні 2016-го відбулась спроба розмороження конфлікту [11]. Однак загалом ситуація відзначалася стабільністю [12].

На жаль, для Республіки Абхазія, ПівденноОсетинської Республіки та Нагірно-Карабаської Республіки все закінчилося війною. Висновок один: якщо маємо територіальні претензіі, то зобов'язані готуватися до гіршого варіанту - війни.

Проведемо аналіз війни у Нагорному Карабасі (2020 рік) через призму ставлення до підготовки та застосування збройних сил сторін конфлікту.

Дві країни, два непримиримих вороги (Азер- байджан та Вірменія) та одна територія - Нагірний Карабах. 28 років чекання - $з$ одного боку та 28 років модернізації Збройних Сил, грамотного оборонного планування, підготовки професійної армії - 3 іншого боку, призвели до розв'язання війни та вирішення багаторічних протиріч силовим, збройним шляхом. Азербайджан зробив ставку в цій війні на авіацію і не помилився. Авіація показує себе як основна ударна компонента в без'ядерній війні та стала основним фактором перемоги.

Саме дотримання концепції Дж. Дуе (перевага в повітрі - це успіх війни) [4], грамотне планування комплексної повітряної наступальної операції дозволило за півтора місяці досягти військовополітичних цілей.

Якщо дивиться на хід збройного конфлікту, то бачимо, що ЗС Азербайджану застосували всі компоненти проведення повітряної наступальної операції (рис. 1):

1) ведення ППО для оборони (прикриття) своїх військ;

2) знищення системи ППО противника;

3) безпосередня авіаційна підтримка військ (сил) у наступі;

4) вогневе ураження критичних елементів противника на всю глибину його оперативної побудови та в глибокому тилу.

Така комплексність стала можлива тільки завдяки розвитку авіації, в першу чергу - безпілотної.

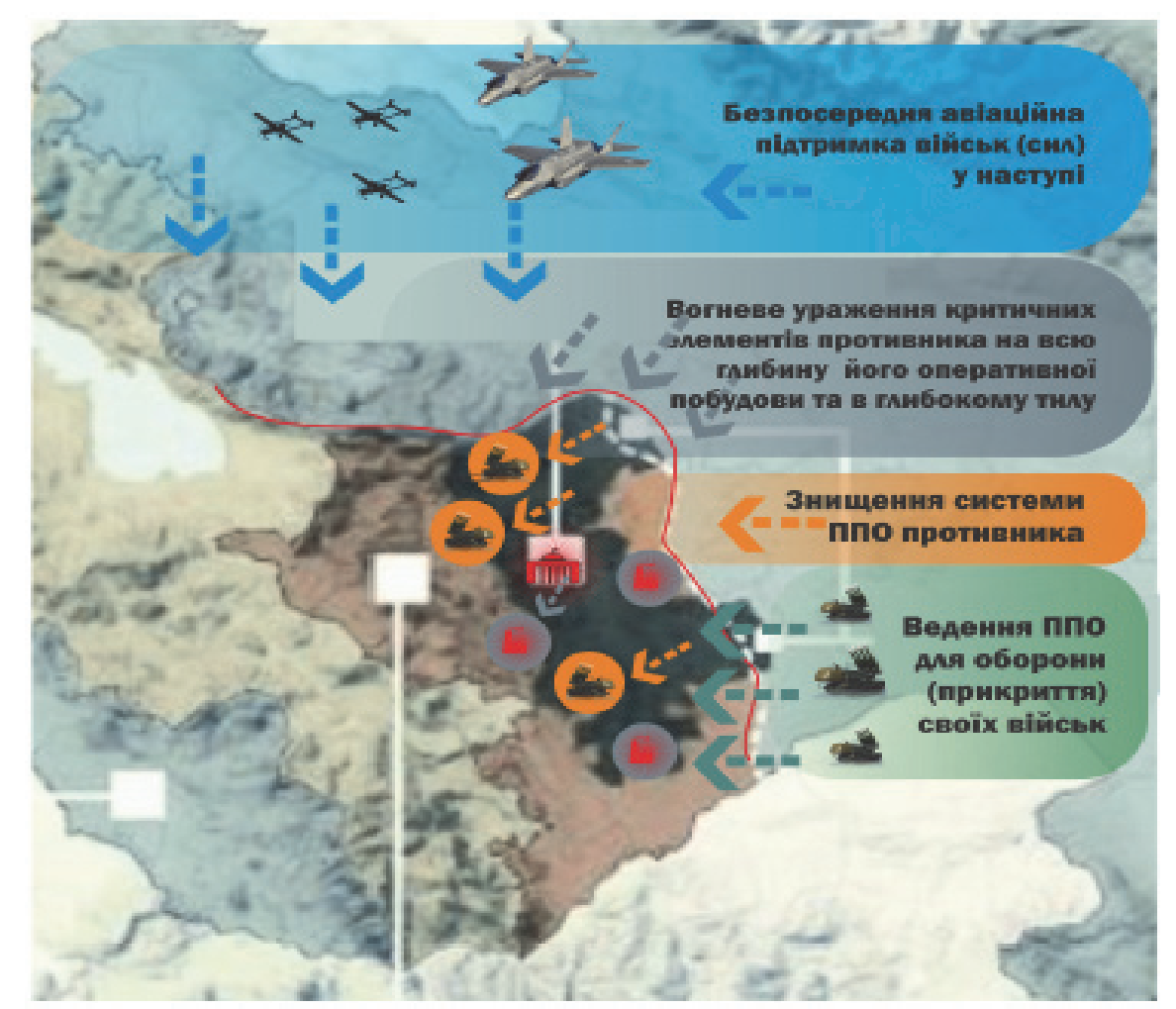

Рис. 1. Компоненти проведення повітряної наступальної операції Джерело: розроблено авторами за даними [4]. 
Азербайджан зробив головне, він адаптував основні принципи, форми і способи застосування складових власних ЗС до вимог збройного конфлікту (операції, яка була проведена). Вірменія, обмеживши застосування власних ЗС завданнями ППО програла. Протиповітряна оборона може бути ефективною тільки тоді, коли вона є комплексною та функціонує в межах єдиної системи. Прикриття військ на маршах, в оборонних та наступальних боях повинно комплексуватися 3 прикриттям важливих державних об'єктів, об'єктів критичної інфраструктури.

Інтегратором даної системи повинні стати система централізованого управління та система комплексної розвідки і радіоелектронної боротьби (РЕБ). Не можна “розривати” систему ППО, бездумно "роздаючи" та "розподіляючи" повітряні командування між оперативними (оперативнотактичними) угрупованнями, не проводячи спільного планування з ППО Сухопутних військ, не створивши єдиної системи управління боротьбою у повітряному просторі.

Система ППО повинна бути комплексною та збалансованою за бойовими можливостями їх вико- ристання. Якщо система Бук-М1 створювалася для прикриття військ у наступі/обороні, то не потрібно іiі використовувати для прикриття стаціонарних об'єктів. Системи (вогневі засоби) ППО Сухопутних військ радянського виробництва, навіть модернізовані, не є ефективними проти сучасних засобів авіації (про війни майбутнього з дронами та високоточною зброєю можна зовсім не згадувати). Вірменією було втрачені майже всі комплекси ППО типу “ОСА”, “Стріла” [11-13], які були придбані у модернізованому варіанті [11] та взагалі не виявили бойової ефективності.

Провівши аналіз бойових втрат переможеного - Вірменії, можна зробити висновок, що від $60 \%$ до 90\% завдань вогневого ураження було покладено на авіацію ЗС Азербайджану, незважаючи на наявність достатньо потужного угруповання ракетних військ та артилерії. Авіація є і залишається тією могутньою силою, яка здатна нанести удар у відповідь, стати стримуючим фактором для агресора або забезпечити перемогу у разі агресії (табл. 1, рис. 2).

I це майже класика розподілу завдань в ході комплексного вогневого ураження.

Таблиця 1

Аналіз частки виконання завдань пілотованою та безпілотною авіацією ЗС Азербайджану під час збройного конфлікту у Нагірному Карабасі

\begin{tabular}{|c|c|c|c|c|c|c|c|c|}
\hline & $\begin{array}{c}\text { ББМ в т.ч. } \\
\text { танки, БТР, } \\
\text { БМП }\end{array}$ & Автомобілі & $\begin{array}{c}\text { Артилерія } \\
\text { в т.ч. САУ }\end{array}$ & РСЗВ & ЗРК & РЛС & $\begin{array}{c}\text { Спец. } \\
\text { техніка }\end{array}$ & Разом \\
\hline $\begin{array}{c}\text { Загальні втрати } \\
\text { Вірменії }\end{array}$ & 256 & 400 & 138 & 72 & 26 & 12 & 64 & 968 \\
\hline $\begin{array}{c}\text { Втрати від дій } \\
\text { авіації (в т.ч. } \\
\text { БПЛА) }\end{array}$ & 160 & 198 & 126 & 71 & 22 & 10 & 44 & 631 \\
\hline $\begin{array}{c}\text { Частка авіації } \\
\text { у знищенні ОВТ }\end{array}$ & $62 \%$ & $49 \%$ & $90 \%$ & $98 \%$ & $84 \%$ & $83 \%$ & $68 \%$ & $65 \%$ \\
\hline
\end{tabular}

Джерело: розроблено авторами за даними [11-12].
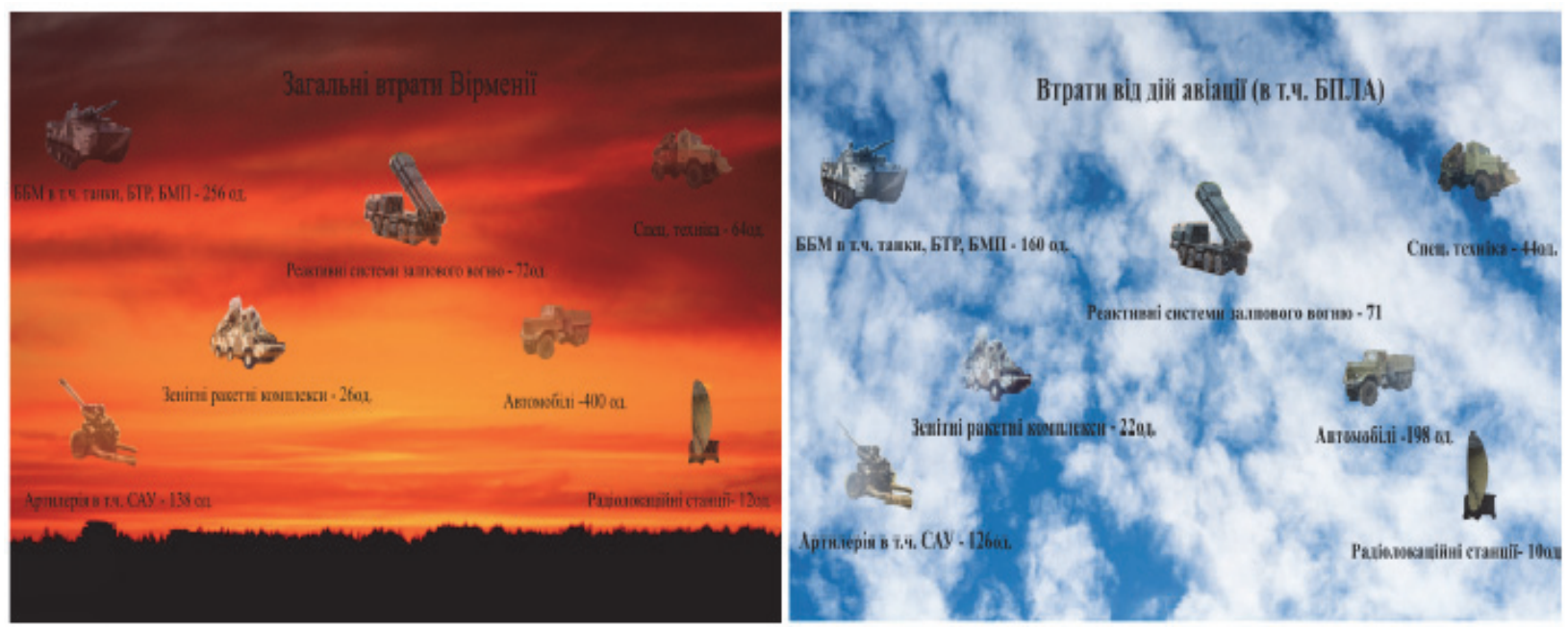

Рис. 2. Аналіз частки виконання завдань пілотованою та безпілотною авіацією ЗС Азербайджану Джерело: розроблено авторами за даними [11-12]. 
Азербайджан реалізовував велику перевагу в повітрі і безпілотні авіаційні комплекси, як і раніше, нанесли втрат більше, ніж всі інші види озброєнь разом узяті.

Особливістю бойових дій в цьому регіоні стало те, що обидві сторони обмежено застосовували пілотовану авіацію. Азербайджан має досить потужні віськово-повітряні сили - в минулі роки країна отримала більше 20 винищувачів Міг-29 і 11 штурмовиків Су-25.

Крім того, на озброєнні перебуває 12 ударних вертольотів Mi-24 і не менше $24 \mathrm{Mi}-35$ - глибоко модернізованою версією Mi-24.

Вірменія, яка підтримує Нагірний Карабах, придбала в Росії більш сучасні і більш потужні, ніж МіГ-29, винищувачі Су-30. У складі вірменських військово-повітряних сил їх всього чотири одиниці, їх Єреван не став відправляти на підтримку формувань Нагірно-Карабаської Республіки. "Цілей не виникло для їх використання. I використовувати їх для полювання на бронетехніку противника не дуже розумно", - сказав військовий експерт Леонід Нерсисян [15]. Крім того, район Нагірного Карабаху виявився настільки насичений засобами ППО обох сторін, що активно застосовувати там пілотовану авіацію не наважувався ніхто - занадто великий ризик втратити літак.

Головною відмінністю при нинішньому загостренні конфлікту в Нагірному Карабасі стало використання ударних безпілотних авіаційних комплексів з ракетно-бомбовим озброєнням.

Даний факт доводить, що авіація повинна розвиватися, необхідно знайти оптимальний баланс між пілотованою та безпілотною авіацією в майбутній моделі Повітряних Сил Збройних Сил України. Тобто нас орієнтують на необхідність адаптувати оборонне планування та державні оборонні закупівлі на війни майбутнього, а не доганяти конфлікти минулого. Вірменія придбала 4 багатоцільових винищувача Су-30СM, які так і не підняли в повітря через високу ціну втрати. Азербайджан за співставні кошти закупив десятки безпілотних комплексів турецького та ізраїльського виробництва, які у підсумку і здобули перемогу.

Чому уроки війни в Нагірному Карабасі актуальні для України.

1) Україна має майже аналогічний конфлікт на території окремих районів Донецької та Луганської областей.

2) Україна побачила, що ефективні стратегічні альянси та непоступлива дипломатія можуть забезпечити перемогу у війні з країною, за якою стоїть Росія.

3) Якби не демонізували Росію у медійному просторі та підносили міць Збройних Сил Російської Федерації - ця країна має свої больові точки та червоні лінії, а її армія не є непереможною.
4) Війна засвідчила переважну роль авіації у перемозі. Країна, що мала та ефективно застосовувала авіацію, бо безпілотна авіація - це теж авіація, яка в найближчий час стане повноправним окремим родом авіації, перемогла.

5) Війна підкреслила, що часткова модернізація озброєння та військової техніки, половинчасті, а іноді не завжди виважені заходи та кроки у реформуванні збройних сил, залишки радянської системи управління та застаріли системи (вогневі засоби) ППО не здатні забезпечити умови для ефективної боротьби із сучасними бойовими системами. Час “радянського озброєння та військової техніки” - вже практично вичерпано.

\section{Висновки}

1) Визначення ролі Повітряних Сил лише 3 позицій оборони є згубним та може призвести до поразки у війні. Авіація - це, в першу чергу, засіб удару у відповідь, засіб для виконання завдань вогневого ураження в глибині оперативної побудови військ противника, ураження його стратегічних (критичних) об'єктів, резервів з метою створення сприятливих умов для виконання завдань угрупуваннями військ (сил), підриву економічних можливостей противника, порушення системи державного та військового управління.

2) Успішне виконання завдань Сухопутними військами спільно з Військово-Морськими Силами Збройних Сил України на приморському напрямку також неможливо без потужної ударної компоненти Повітряних Сил, яка здатна створити сприятливі умови для їх успішного застосування.

3) Час радянських бойових систем минув, ресурс їх модернізації на межі повного вичерпання. Вони можуть ще заспокоювати нас на парадах, однак критично не ефективні на полі бою. Комплексна система розвідки, інформатизація всіх процесів управління, адаптивна централізована система управління, авіаційні розвідувально-ударні роботизовані комплекси XXI століття - стають зброєю перемоги.

Війни не починаються просто так і раптово вони не закінчуються. Кожній війні передує підготовка: виважена, грамотна, ефективна - 3 боку переможця, ситуативна, половинчаста - 3 боку переможеного. Для того, щоб не бути переможеним, потрібно вчитися, бажано вчитися на помилках інших.

Оборона країни - це завжди дорого. Годувати чужу армію, втративши суверенітет, території та національну гідність - це завжди дорожче.

Вірмени після поразки у Нагірному Карабасі палили власні будівлі, готуючись до неминучої еміграції. Це тому, що вони не готувалися ефективно знищивати літаки та танки противника у мирний час. 


\section{Список літератури}

1. Рябчик Ю.Р. Философия войны и теория управления современным противоборством. / Ю.Р. Рябчик, В.И. Ничипор // Военная мысль. - 2007. - № 8. - С. 65-73.

2. Паршин С.А. Современные тенденции развития теории и практики управления в вооруженных силах США / С.А. Паршин, Ю.Е. Горбачев, Ю.А. Кожанов. - М.: ЛЕНАНД, 2009. - 272 с.

3. Аналіз форм і способів застосування збройних сил у локальних війнах та збройних конфліктах сучасності: Звіт про оперативне завдання. - Х.: ХУПС, 2011. - 64 с.

4. Еволюційні зміни у підходах щодо проведення повітряної наступальної операції на прикладі локальних конфліктів у Лівії (1986 рік, 2011 рік) / С.В. Лазебник, В.В. Тюрін, І.М. Тіхонов, В.В. Грідіна // Системи озброєння і військова техніка. - 2013. - № 4(36). - С. 142-145.

5. Лазебник С.В. Розвиток оперативного мистецтва, форм та способів застосування Повітряних Сил / С.В. Лазебник, В.Г. Малюга, О.М. Місюра // Збірник наукових праць Харківського національного університету Повітряних Сил. 2017. - № 5(54). - C. 15-18.

6. Шамко Є.В. Основні особливості застосування Повітряних Сил в сучасних умовах ведення збройної боротьби / Є.В. Шамко, О.М. Жарик, В.В. Коваль // Наука і техніка Повітряних Сил Збройних Сил України. - 2017. - № 2(27). C. 15-18. https://doi.org/10.30748/nitps.2017.27.02.

7. Офіційний сайт Air Force Command of UA Armed Forces. Візія Повітряних Сил 2035, затверджена Військовою Радою Повітряних Сил від 15.05.2020 року. - Режим доступу: https://www.facebook.com/kpszsu/posts/2773107272967335/.

8. Шамко В.С. Розвиток форм і способів застосування Повітряних Сил Збройних Сил України в сучасних умовах ведення збройної боротьби / В.Є. Шамко, О.М. Жарик, В.В. Коваль // Наука і техніка Повітряних Сил Збройних Сил України. - 2018. - № 2(31). - С. 9-15. https://doi.org/10.30748/nitps.2018.31.01.

9. Гібридна війна: in verbo et in praxi: монографія / Донецький національний університет імені Василя Стуса; під. заг. ред. проф. Р.О. Додонова. - Вінниця : ТОВ “Нілан-ЛТД”, 2017. - 412 с.

10. Магда Є.М. Гібридна війна: вижити і перемогти / Є.М. Магда. - Харків: Віват, 2015. - 304 с.

11. Офіційний сайт ВВС. Чому Азербайджан виграв війну у Карабаху? Відповідають військові експерти. - Режим доступу: https://www.bbc.com/ukrainian/features-54912350.

12. Офіційний сайт Deutsche Welle. Війна Вірменії та Азербайджану за Карабах: що приніс місяць боїв. - Режим доступу: https://www.dw.com/uk/viina-virmenii-ta-azerbaidzhanu-za-karabakh-shcho-prynis-misiats-boiv/a-55423675.

13. Офіційний сайт 5.UA. Нагірний Карабах: Хто найбільше виграв від завершення війни та які висновки може зробити Україна. - Режим доступу: https://www.5.ua/svit/nahirnyi-karabakh-khto-naibilshe-vyhrav-vid-zavershennia-viiny-taiaki-vysnovky-mozhe-zrobyty-ukraina-228953.html.

14. Офіційний сайт ВВС. Нагірний Карабах: хто виграв і що далі? - Режим доступу: https://www.bbc.com/ ukrainian/features-54887608.

\section{Вidомості про авторів:}

\section{Жарик Олександр Миколайович}

Заступник начальника штабу

Повітряних Сил Збройних Сил України

Командування Повітряних Сил Збройних Сил України,

Вінниця, Україна

https://orcid.org/0000-0002-0915-4327

\section{Тристан Андрій Викторович}

доктор технічних наук

старший науковий співробітник

начальник науково-дослідного управління

Харківського національного університету

Повітряних Сил ім. І. Кожедуба,

Харків, Україна

https://orcid.org/0000-0003-0494-8125

\section{Information about the authors:}

\section{Oleksandr Zharyk}

Deputy Chief of Staff

of the Air Force Command

of the Armed Forces of Ukraine,

Vinnytsia, Ukraine

https://orcid.org/0000-0002-0915-4327

\author{
Andrii Trystan \\ Doctor of Technical Sciences \\ Senior Research \\ Chief of Scientific Research Department \\ of Ivan Kozhedub Kharkiv National \\ Air Force University, \\ Kharkiv, Ukraine \\ https://orcid.org/0000-0003-0494-8125
}

\section{ВОЕННАЯ ОПЕРАЦИЯ АЗЕРБАЙДЖАНА В НАГОРНОМ КАРАБАХЕ В КОНТЕКСТЕ РАЗВИТИЯ ВОЗДУШНЫХ СИЛ ВООРУЖЕННЫХ СИЛ УКРАИНЫ}

А.Н. Жарик, А.В. Тристан

Военные конфликты ХХІ века, в том числе в Нагорном Карабахе, являются свидетельством который раз доказывающим: страны, которые имеют “нестабильные", спорные территории, должны готовиться к войне, а тщательная подготовка к проведению воздушной наступательной операции - необходимость, которой нельзя пренебречь. 
Авиация была и остается сдерживающим фактором для стран агрессоров, так большинство боевых потерь Армении причинены именно авиацией Вооруженных Сил Азербайджана. Особенностью подобных конфликтов является увеличение доли в проведении воздушных операций беспилотной авиачии - ударных беспилотных авиационных комплексов с ракетно-бомбовым вооружением, что обусловлено высокой ценой потерь пилотируемой авиации.

В работе обобщены выводы войны в Нагорном Карабахе для Воздушных Сил Вооруженных Сил Украины и разработаны рекомендации по их подготовке к вооруженным конфликтам современности и будущего.

Ключевые слова: “замороженный” конфликт, вооруженный конфликт, воздушная наступательная операция, развитие Воздушных Сил, беспилотный и пилотируемая авиации, подготовка и ведение военных операций.

\title{
MILITARY OPERATION OF AZERBAIJAN IN NAGORNO-KARABAKH IN THE CONTEXT OF DEVELOPMENT OF THE AIR FORCES OF THE ARMED FORCES OF UKRAINE
}

\author{
A. Zharyk, A. Trystan
}

The military conflicts of the 21st century, including in Nagorno-Karabakh, are evidence that once again proves: countries that have "unstable", disputed territories should prepare for war, and careful preparation for an air offensive operation - the necessity of which cannot be neglected. components of the air offensive operation of the aggressor in the Nagorno-Karabakh conflict were: conducting air defense to protect (cover) their troops; destruction of the enemy's anti-aircraft system; direct air support of troops (forces) in the offensive; effective engagement of critical elements of the enemy to the full depth of his operational formation and deep in the rear.

Aviation was and remains a deterrent factor for the aggressor countries, as most of Armenia's combat losses were caused by the aviation of the Armed Forces of Azerbaijan. A feature of such conflicts is an increase in the share of unmanned aircraft in air operations - unmanned attack aircraft systems with missile and bomb weapons, which is due to the high cost of losses of manned aircraft. The war showed the great role of aviation in victory.

The country, which had and effectively used aviation, because unmanned aviation is also aviation, which in the near future will become an independent branch of aviation, won. This fact proves that aviation must develop, it is necessary to find an optimal balance between manned and unmanned aircraft in the future model of the Air Force of the Armed Forces of Ukraine. That is, we are guided by the need to adapt defense planning and government defense procurement for the wars of the future, and not catch up with the conflicts of the past.

The article summarizes the conclusions of the war in Nagorno-Karabakh for the Air Force of the Armed Forces of Ukraine and developed recommendations for their preparation for armed conflicts of today and the future.

Keywords: "frozen" conflict, armed conflict, air offensive operation, development of the Air Force, unmanned and manned aviation, preparation and conduct of military operations. 